\title{
Chapter 3. \\ INTEGRATING NOMINATIVE DATA ON THE ORTHO- DOX AND GREEK CATHOLIC CLERGY IN MODERN TRANSYLVANIA: AN OUTLINE ${ }^{1}$
}

\section{Marius Eppel, \\ Oana Sorescu-Iudean,}

Writing in the late 1830s, the British traveller John Paget described the Romanian clergy near the former Roman-era settlement of Densus, in the County of Hațeg in Transylvania, noting that "except for a somewhat greater neatness of person, and the long black beard which hung down to his breast, the Wallack priest was in no way distinguished from the humblest of his flock." Perhaps surprisingly for a traveller used to the ranks of the Anglican Church, the figures of the Romanian (likely Orthodox) ecclesiastical hierarchy were in many respects similar to those whom they shepherded: "With just enough education to read the service of the church, just enough wealth to make them sympathize with the poor, and just enough religion to enable them to console them in their afflictions, these men exercise a greater power over the simple peasant than the most cunning Jesuit, the most wealthy Episcopalian, or the most rigid Calvinist" (Paget, 1839, p. 202). Despite the characteristic traveller's lens through which Paget viewed the Romanian clergy in Transylvania, as well as most of the affairs in Hungary at the time (Bökös, 2017), the account was deemed, even by contemporary Hungarians, to be quite "effective" in describing the area's characteristics (Popova-Nowak, 2008, p. 215). It is therefore likely that the image of the clergy as an historical actor who wielded a great deal of influence over the communities of faithful was not far from the truth. Nevertheless, the extent to which the placement of the Romanian clergy on the social-economic ladder in the province conforms to the same image remains an open question.

Within the specific milieus of the composite state of the Habsburg Empire, and after 1867, Dualist Hungary, social-occupational groups such as the clergy, who could mobilize the great, critical mass of the

1 The study was supported through the grant CNCS - UEFISCDI, project no. PN-III-P4-ID-PCE-2016-0661. 
peasantry towards more secular purposes, along with the entrenchment of nationalism, were of crucial importance (Hitchins, 1994, p. 169-170). Despite the flourishing of a consistent strand of ecclesiastical historiography in the past two decades, the Romanian clergy in Transylvania remain largely an unknown quantity in many respects. Leaving aside various narrative accounts, contemporary press articles, or other textual sources, the middle clergy - the parish priests - have not been studied comprehensively from the perspective of their inner structural roles within the mosaic of nations and confessions present in the area. What is more, apart from fragmentary studies, they have rarely been dealt with as a self-standing category, which straddled the ranks of the elite and those of the great majority of the rural population.

This paper proposes to outline the development of a database that will enable historians to obtain a much-needed systematic view of this social and professional category in the multi-denominational and multiethnical state of Dualist Hungary, focusing primarily on the basic, lowest level, that of the individual mid-level clergyman and the parish, the two building blocks of the national-ecclesiastical construct. As many other recent projects seeking to implement a digital approach to historical sources concerning a social-professional group have evidenced, a substantive account of the way in which the database has been envisaged and designed is direly necessary in order to open it towards a wider category of scholars and to place it firmly within the realm of traditional historical endeavours. The present study will therefore adopt a fourfold structure: it will firstly provide a brief overview of the literature concerning the Romanian middle clergy during modernity from a structural perspective, noting this group's entanglements with other fields of history apart from the ecclesiastical sphere; secondly, it will situate the database into the recently flourishing landscape of digital initiatives focused on similar categories in other regions or timeframes; thirdly, it will outline the "universe" of the database (Mandemakers, Dillon, 2004), focusing on the core sources used, their characteristics, and the extent to which they can be integrated into a common data structure; finally, it will offer a preliminary sketch of the database, focusing on the main entities - individuals, offices, and parishes.

\section{The Romanian Middle Clergy as Historical Actor: A Brief Overview}

Throughout the nineteenth and early twentieth centuries, and especially after the establishment of Dualism, competing national demands 
made themselves increasingly felt in Transylvania as in many other composite territories of the Dual Monarchy. Since early modernity, Transylvania had been home to some nine ethnic groups (Romanians, Hungarians, Germans, Slovaks, Ruthenes, Jews, Croats, Serbs, and Gypsies), resulting in a conglomerate which overlapped partially with a diverse landscape of confessions (Holom, Sorescu-Iudean, and Hărăguș, 2018, p. 331-333). The Romanians in the area had either remained part of the Greek Orthodox denomination, or had adhered to Greek Catholicism, a Church united with Rome, but which had nevertheless maintained its confessional and national distinction (Brusanowski, 2017, p. 187-197). Both Romanian Churches have been the object of consistent research endeavours, which have adopted various perspectives. Given the limits of the current paper, we will single out only a few exemplary studies that showcase the approaches employed, as well as the important structural positions occupied by the middle clergy within Transylvanian society and the Hungarian state, after 1867.

Essential for the understanding of the frameworks and evolutions of the two Romanian churches are first and foremost the general ecclesiastical histories, which mainly focus on the activity of the highest ranks of the clergy, on institutional development, and on the process of confessional definition. For the Greek Catholic Church, the ties established with the Holy See are of prime importance in understanding most of these aspects (Sima, 2013). Worth noting, though they mainly tackle eighteenth- or early nineteenth- century developments are the recent histories of the Greek Catholic Church (Dumitran, 2007; Nedici, 2013) as well the older but still authoritative work by Genț (1912), which provides a detailed image of the various waves of administrative reorganisation during the nineteenth century. What might be termed traditional ecclesiastical histories, though written from an avowedly confessional perspective, are still the primary reference point for researchers dealing with the evolution of the Orthodox Church in Transylvania (Floca, 1990; Păcurariu, 2013). More recently, the works by Brusanowski have shed light on the institutional growth and definition of the Orthodox Church and its confessional educational system $(2005,2007)$. The structural parallels between the two Romanian Churches during the modern period have also been briefly analysed in a recent study (Cârja, 2007a). A greater proliferation was witnessed by case studies of various breadths, ranging from examinations of ecclesiastical jurisdictions such as vicarages (Andrei, 2006) or deaneries (Covaci, 2007) to single communities (Panțuru, 2013). As part of these well-circumscribed endeavours, historians have also focused on publishing the plentiful source material 
produced by various ecclesiastical structures (Suciu et al., 2011). However, by far the most abundant strand of research has targeted individual clerical figures, generally of higher ranks, either by adopting a biographical approach (Cârja, 2007b) or by employing a prosopographic framework through which the lives and activities of certain sub-groups of clergymen were recovered as part of the current historiography focused on elites (Popa-Andrei, Covaci, and Sima, 2013). This latter type of analysis has also been spurred by the current tendency to offer an in-depth view of those historical figures who played a direct part in the events marking the end of the First World War and the establishment of the Greater Romanian state in 1918 (Dăncilă-Ineoan, Iudean, 2018). Issues that have a direct bearing on the structural development of the two Romanian Churches such as the conversion of entire communities from one denomination to the other have also been explored, but only for select deaneries (Drăgoi, 2011). Most of the abovementioned studies have also dealt at least cursorily with questions stemming from the sphere of social history, such as the perpetuation of the clerical profession both intra and inter-generationally, the recruitment of priests (Popa-Andrei, Covaci, Bedecean, et al., 2014; Popa-Andrei, Covaci, 2013) the social and economic status of priests within various communities or milieus, their national activism, etc. Recently, researchers have also dealt with issues such as the pension system implemented for the Greek Catholic clergy in the latter half of the nineteenth century (Covaci, 2012).

Nevertheless, the research landscape remains deeply fragmented, and case studies, though detailed, cannot encompass broader jurisdictional forms, especially those wider than the diocese. As in the case of other national ecclesiastical institutions, such as for instance the Anglican Church, no definitive aggregate figures exist for the number of clergymen activating in Transylvania from the mid-nineteenth to the early twentieth century (Burns, Fincham, Taylor, 2004, p. 729). Analyses that rely on aggregate data for one diocese or another also necessarily eschew individual-level approaches, outside of brief narrative intermezzos. These in turn can only exemplify subjectively selected tendencies, mainly adhering to commonplaces already noted in historiography, rather than help to clarify the origins and results of broader patterns in the social and geographic mobility of priests or the economic and geographic characteristics of parishes. The salience of this group has also been emphasized by works examining the numerous entanglements between the clergy and the Romanian national movement (Hitchins, 1994, p. 169-220), the banking system (Balog, 2014), and the Romanians' 
main cultural association in Transylvania (Popovici, 2018). It can therefore be stated that obtaining a clear image of those who composed this group, their attributes, as well as those of the frameworks within which they exerted their offices is paramount to understanding not only the clergy, but also the institutional history of Transylvania, in its broadest sense.

\section{The Confessional Infrastructures Database within the Current Digital Landscape ${ }^{2}$}

Certainly, the initiative to map out professional categories or educationally-circumscribed groups within a certain territory, especially during the nineteenth and twentieth centuries, is not a wholly novel enterprise. Researchers have attempted to flesh out the staff of the Imperial court in early modern Vienna by means of an extensive relational database ${ }^{3}$ (Kubiska-Scharl, Pölzl, 2013), or to document the medieval and early modern graduates of faculties throughout the Holy Roman Empire $^{4}$ (Gubler, Schwinges, 2018), by implementing digital systems to deal with wide-ranging prosopographic accounts. The records produced by various churches within Europe have likewise not escaped the digital gaze within the past decade, as, compared to sources produced by other types of institutional actors, and depending on the historical period, they offer an incomparable wealth of information. What is more, the structural uniformity characterising the Churches present throughout Europe results in similarly structured records, that either allow for the creation of structured datasets, or are especially promising for various social-historical endeavours. ${ }^{5}$ An example of the latter type of approach is the Consistory Database, which contains deposi-

2 The database as well as a comprehensive user manual and source documentation will be available starting June 2019 at http://confinfrahist.granturi.ubbcluj.ro/. For a brief review of the project itself, see http://www.elite-research.eu/Socio-professional\%20trajectories.html.

3 "Personnel and Organization of the Viennese Court (1711-1806) - organizational and prosopographical studies on the early modern Viennese Court", https://www. univie.ac.at/hofpersonal/en/the-project/ (accessed December 2018).

4 „Repertorium Academicum Germanicum, Die graduierten Gelehrten des Alten Reiches zwischen 1250 und 1550“, https://rag-online.org/ (accessed December 2018).

${ }^{5}$ We are excluding from this brief overview perhaps the most wide-ranging databases dealing with Church-produced records, namely the historical population databases integrating information from parish registers. For an overview of the majority of existing population databases, see https://ehps-net.eu/databases (accessed December 2018). 
tions offered in late medieval trials held before the London Consistory, and deserves to be highlighted among such endeavours. ${ }^{6}$ What is more, the Church's potential to produce reliable statistical records has long been recognized by both early modern states and contemporary researchers, as evidenced by projects such as that of the Statistical Accounts of Scotland Online, which recently centralized in an accessible document portal the accounts produced by eighteenth and nineteenth century Scottish parish ministers at the initiative of Sir John Sinclair. ${ }^{7}$ The focus on the material side of ecclesiastical infrastructures has also recently come to the fore of digital research, yet again in the English milieu, with projects such as that making use of the churchwardens' accounts of England and Wales, soon to be released online. ${ }^{8}$ Finally, the closest methodological "relative" of our current endeavour is the "Clergy of the Church of England Database" (CCEd), which provides a digital infrastructure populated with the careers of all clergymen in England from 1540 to 1835.

While our current endeavour shares many common traits with those briefly noted above, the specificity of the region, timeframe, and sources under question lend it a distinct character. First, it focuses on both the clergy as individual historical actors, attempting to reconstruct their educational and professional pathways, as well as on the confessional infrastructures in which they functioned. As opposed to previous projects, it integrates data from two different denominational strands - the Orthodox and the Greek Catholic - which will aid future researchers to bridge the denominational divide in the study of the Romanian ecclesiastical culture, an issue that is currently difficult to overcome due to the breadth of records and the differences in practices. Secondly, as will be detailed further, it seeks to provide a platform to integrate a significant variety of historical sources, both narrative and structured. In this sense, a primary goal is to remain open-ended in a certain sense, allowing future researchers to complement the broad image resulting from present data entry efforts with smaller-scale but more in-depth records tied to entities already present in the database. What is more, the current project goes beyond the recording, standardisation, and linkage of clerical careers in modern Transylvania, by delving into the con-

${ }^{6} \mathrm{http}: / /$ consistory.cohds.ca/ (accessed December 2018).

7 "The Statistical Accounts of Scotland 1791-1845", https://stataccscot.edina. ac.uk/static/statacc/dist/home (accessed December 2018).

8 "The Churchwardens' Accounts of England and Wales", https://warwick.ac.uk/ fac/cross_fac/myparish/projects/cwa/ (accessed December 2018). 
fessional infrastructures themselves and integrating data related to the material patrimony of parishes, ecclesiastical and school buildings, and other ecclesiastical administrative structures (diocese-level schools, chapters, etc.). Finally, like the initiative targeting the churchwardens' accounts of England and Wales, it seeks to provide timestamped images of ecclesiastical organisation and jurisdiction, which will be tied to the secular administrative organisation in the area, as revealed in the censuses of 1850-1910.

\section{The "Universe" of the Database: Sources and Challenges}

This section will briefly chart the "universe" of the database, as per the recommendations outlined by Mandemakers and Dillon (2004). A fuller account of all these issues will be offered on the database website, well before its public release, as well as in a further study documenting the structure of the database upon the completion of the project.

It should firstly be noted that our endeavour focuses on the Greek Catholic and Orthodox clergymen from two major ecclesiastical administrative units in Transylvania: the Greek Catholic diocese of Alba Iulia and Făgăraș, and the Orthodox diocese of Sibiu. These two units were the most important for each confession, seeing as they housed the decision-making centres of the Greek Catholic and Orthodox Churches in Transylvania. The diocese of Alba Iulia and Făgăraș (previously Făgăraș) was established as such in 1850 and was raised to the rank of Greek Catholic metropolitan see or archdiocese in 1855. Likewise, the diocese of Sibiu was among the oldest Orthodox dioceses in Transylvania, and became an autonomous metropolitan see in 1864 . We have also hypothesised, based on previous surveys, that due to their centrality and rank within the entirety of the ecclesiastical structures of the two Churches, the two dioceses generally also produced reliable records and allowed the highest ranks of the clergy to transmit information to the lowest ranks with more ease and accuracy (Sima, Covaci, 2015).

Throughout the nineteenth and early twentieth century, both Romanian Churches in Transylvania produced a type of record generally referred to in secondary literature as schematismae, or yearbooks. These sources were not a specific product of modern Transylvanian ecclesiastical milieus, but rather a kind of record generated by the Catholic or United Catholic Church throughout Europe since early modernity. Church schematisms mapped out the entirety of the positions within the ecclesiastical hierarchy for a certain unit such as a diocese, from the 
highest to the lowest level, and listed the individuals occupying each office at a certain point in time. Such sources were produced for instance in the historical dioceses from nowadays Ukraine during the $1840 \mathrm{~s}$ and $1850 \mathrm{~s}^{9}$, in most German bishoprics since the middle age ${ }^{10}$, in historical Polish ${ }^{11}$ or Hungarian dioceses. ${ }^{12}$ Almost structurally identical sources were also produced by the imperial Habsburg court, initially only for the court staff in Vienna, and later on for the entire administrative apparatus in its provinces (Kubiska-Scharl, Pölzl, 2013). Despite the perceived discursive split characteristic to the process of confessionalization in East-Central Europe, the Protestant and Reformed Churches also adopted this mechanism in order to maintain a clear image of their infrastructures and staff, producing highly similar records. ${ }^{13}$ Despite the regional specificities of the institutions producing them and the resulting professional attributes of the persons listed therein (clerical officials, military officials, state officials, etc.), these types of sources are widespread throughout Europe, and have close equivalents even on the British Isles, in the so-called libri cleri, registers of appointments, or licensing books (Burns, Fincham, Taylor, 2004, p. 730). We may therefore state that, as far as the potential to create internationally-compatible datasets and to conduct transnational analyses of the parish clergy is concerned, these types of sources are extremely well-suited.

The ecclesiastical schematisms or yearbooks produced by the two Romanian Churches became more widespread in Transylvania starting from the middle of the nineteenth century, most likely tying into the administrative reforms that led to the establishment of the two archdioceses. Certainly, these sources were not the first attempts by the Church or the state to obtain a clear image of ecclesiastical infrastruc-

${ }^{9}$ Schematismus Universi Venerabilis Cleri Archidioeceseos Metropolitanae Graeco Catholicae Leopoliensis pro Anno Domini 1851, http://dlibra.kul.pl/dlibra/docmeta data?id=14621\&from=publication (accessed December 2018);

${ }^{10}$ Schematismus der Geistlichkeit des Bisthums Eichstätt für das Jahr 1480, http://gateway-bayern.de/BV013883416; Schematismus der Geistlichkeit des Bistums Augsburg : für d. Jahr 1865, http:/www.mdz-nbn-resolving.de/urn/resolver. pl?urn=urn:nbn:de:bvb:12-bsb10383077-2 (both links accessed December 2018).

${ }^{11}$ Schematismus der Geistlichkeit des Bisthums Breslau für das Jahr 1846, http:// www.dbc.wroc.pl/dlibra/docmetadata?id=2790\&from=publication; (accessed December 2018).

12 „Sematizmusok és összeírások”, http://byzantinohungarica.hu/node/141 (accessed December 2018).

${ }^{13}$ Statistisches Jahrbuch der Evangelischen Landeskirche AB im Großfürstenthum Siebenbürgen, 1870, http://mdz-nbn-resolving.de/urn:nbn:de:bvb:12-bsb10483871-5 (accessed December 2018). 
tures within this territory. Starting from the 1730s-1740s, the Habsburg authorities would request that both the Greek Catholic and Orthodox submit conscriptions of church property, and of the number of families or households in their respective communities, as an instrument to aid in the definition of confessional policy in the province (Dumitran, 2007, p. 168-220). Many of these conscriptions were edited throughout the nineteenth and early twentieth centuries, with varying degrees of accuracy, while their findings would constitute points of contention within the competing national narratives of the late nineteenth century (Câmpeanu, 2003, p. 116-117). Nevertheless, due to significant variance in the quantity and completeness of information provided by these eighteenth-century sources as compared to their nineteenth-century equivalents, the current project will eschew their data entry and integration at this time. What is more, as many eighteenth-century conscriptions were carried out at the behest of or by imperial-appointed authorities in Transylvania, significant doubts have been expressed regarding their accuracy and completeness. Certainly, this does not wholly eliminate the possibility of deepening the current data entry efforts into these sources in the future, as faulty data can be corrected or complemented by appealing to other serial sources stemming from local ecclesiastical archives.

Church schematisms were initially published yearly, as part of calendars. In the case of the Orthodox Church, this rhythm of publication would survive. Up to date, the present project has entered the schematisms for the Orthodox archdiocese of Sibiu from 1882 to 1914, totalling over 73000 lines. The Greek Catholic schematisms were only published periodically, roughly every decade or more often, thus resulting in cross-sectional views of the state of the confessional infrastructures and staffing. ${ }^{14}$ However, on bicentennial anniversaries of the establishment of a certain diocese, the Greek Catholic Church published detailed histories of the staffing and administrative organisation of the respective ecclesiastical unit. This was the case for the Schematism for the Archdiocese of Alba Iulia and Făgăraș of 1900, which included all known clergymen who had activated in the parishes part of the deaneries in the diocese since 1733 and up to 1900 . At the end of this schematic account, small-scale prosopographic accounts of those clergymen who were active in the diocese in 1900 were also added. What is more,

14 The Greek Catholic schematisms have been digitised by the Library of the Romanian Academy in Cluj-Napoca and are available at http://www.biblio.acad-cluj. ro/?q=node/4. Further digitized schematisms are also available online at http://byzantinohungarica.hu/node/141 (both links accessed December 2018). 
Greek Catholic schematisms were prefaced by detailed biographical accounts of the major figures in the higher ranks of the clergy. Presently, this schematism has already been entered as raw data and is undergoing standardisation. For the Orthodox archdiocese of Sibiu, the schematisms were complemented by so-called "Soul Protocols" (Protocoalele sufletelor), which contained information on the clergymen ordained and appointed in the parishes of the diocese, including the dates of ordainment. These types of sources were available at the ecclesiastical archives in Sibiu. Presently, the project team has managed to enter the information from these protocols for the years between 1857 and 1868 . What is more, on certain years, each entry for a certain parish also contains demographic information, listing the total number of Orthodox individuals, of deceased individuals, or births (all by gender), as well as the number of marriages contracted. Information on the historical collection of data for the Greek Catholic schematisms is available in ecclesiastical circulars, issued by the respective diocese roughly one year prior to the publication of the schematism itself. ${ }^{15}$

As far as the estimation of source reliability is concerned, nineteenth century schematisms fare much better than their eighteenth-century correspondents. As has been noted, the anniversary accounts list the entirety of the clerical staff in the diocese for a period of two centuries and note all administrative changes in the diocese (i.e. to which deanery a certain parish belonged, at a certain point in time, and how this hierarchical relationship evolved). What is more, each parish entry contains information on the confessional make-up of the community: the figures for each confession outside of the primary, Greek Catholic one, are taken from the census conducted by the Hungarian state in the same year. It is therefore possible to compare state-derived figures with those provided by ecclesiastical authorities, and to ascertain whether any areas showed significant discrepancies. The series of Orthodox soul protocols, though incomplete in their recording, also allow the comparison of these figures, at least for the Orthodox population in Transylvanian communities. Given the high stakes of a community or area's confessional structure in a multi-denominational and multi-ethnical region, where the state began to enact de-nationalising legislation towards the later decades of the nineteenth century, the ability to compare statedriven recording initiatives with data stemming from the communities

15 Serviciul Județean Alba al Arhivelor Naționale (hereafter abbreviated as SJANA), Fund Mitropolia Română Unită Blaj, Administrația Centrală Arhidiecezană, folder 1/1910, ff. $177 \mathrm{v}-178 \mathrm{v}$. 
themselves (recorded by parish priests) is quite significant.

These types of sources - schematisms and soul protocols - represent the current core of the database initiative and will form the backbone to which other kinds of serial records will be appended in the future. The choice of these core-records was a natural one, as they provide a complete image of the staffing and infrastructures of the two Romanian Churches in Transylvania. ${ }^{16}$ The next sources that we plan on introducing into the database "universe" consist in registers containing information on the priests ordained at the theological academy of Blaj (the centre of the archdiocese of Alba Iulia and Făgăraș) starting with $1869^{17}$, on the widows and orphans of priests in the same diocese and their financial support ${ }^{18}$, and on the situation of vacant parishes in the diocese in the early twentieth century. ${ }^{19}$

\section{Database Structure: A Cursory Overview}

As the database design process is not complete at the time, and the general user interface has not yet been created, this section will only provide a cursory overview of the main principles behind the process of construction, with reference to concrete cases and source contents.

The concept of the database is a quite simple one, inspired by two already extant database models: the source-oriented Historical Population Database of Transylvania ${ }^{20}$ and the research-oriented Historical Data Grinder. ${ }^{21}$ Like the latter, we adopted an entity-attribute-value model, but owing to the experience of introducing a digital solution to the field of traditional historical scholarship, we decided on keep-

${ }^{16}$ Selected images from the source material, singling out and explaining their structural elements at variable level will be available on the project website by the end of 2019.

${ }^{17}$ SJANA, Fund Academia Teologică Greco-Catolică Blaj, folder J1/1869-1948, Protocolul preoților ordinați în Arhidieceza gr.cat. de Alba-Iulia și Făgăraș începând cu anul 1869.

${ }^{18}$ SJANA, Fund Mitropolia Română Unită Blaj, Arhiva Generală, folder 13/18901922, Conspectul preoteselor văduve şi al orfanilor de preoți din Archidiecesa gr. cat. de Alba-Iulia și Făgăraș.

${ }^{19}$ SJANA, Fund Mitropolia Română Unită Blaj, Administrația Centrală Arhidiecezană, folder 201/1907-1916, Protocolul parohiilor vacante în Arhidieceza gr.cat. de Alba Iulia și Făgaraș.

${ }^{20}$ Historical Population Database of Transylvania, https://ehps-net.eu/databases/ historical-population-database-transylvania-1850-1914 (accessed December 2018).

${ }^{21}$ Historical Data Grinder, http://82.208.133.141:3030/ (accessed December 2018). 
ing closer to the original source structure as a means of increasing this instruments' accessibility in the future. The database is presently structured into several main and several secondary tables: a source table, separate tables for each kind of ecclesiastical administrative unit (diocese, deanery, vicarage, parish), a table containing individuals, a table containing all ecclesiastical offices mentioned in the sources, a table for what we have termed "ecclesiastical administrative structures", which contains information on ecclesiastical courts, chancelleries, and the like, and a table linking individuals to offices and to certain ecclesiastical administrative units at certain points in time. Source-faithful spreadsheets were created over the past year and half of project implementation, have been broken up into their respective constitutive entities at the highest possible level of granularity, and are currently being standardised. The lowest level of ecclesiastical structure - the parish - is also linked to a table of localities, extracted from the censuses of 1850-1910 (each census counts as one source, so that the timestamps of ecclesiastical sources and those of secular sources correspond): the parish of Aiud (with id 1, of deanery id 1, of diocese id 1) is therefore linked to the locality no. 1 of a certain constituency and county, as per the census hierarchy. This was not always a straightforward process, as parish as well as place names were not only presented in several languages (Romanian, Hungarian, Latin), depending on the source, but could also change over time. Despite the increased time allocated to data entry and standardisation involved by creating direct correspondences between ecclesiastical and lay administrative units over time (exclusively for the two dioceses under study), we believe that this will aid in future projects seeking to analyse the entanglements between the Church and the lay authorities, shedding light for instance on the factors determining the involvement of parish priests in certain temporal matters, such as elections, national associations, etc. Moreover, the allocation of source timestamps that will be attributed to a certain makeup of the ecclesiastical administration of the two dioceses will enable researchers to examine the evolution of this infrastructure over time, as well as cross-sectionally. As these snapshots of confessional infrastructures had previously been disparate, only tenuously tied in individual studies of deaneries or communities or in cumbersome sources, the longitudinal history of parishes or deaneries could not be described fully.

The individual table will contain the typical fields encountered in serial sources (first name, last name, nickname, title, noble particle, gender, etc.), and will be linked both to the offices table, as well as to vari- 
ous educational institutions or to various ecclesiastical administrative structures (diocese level courts, etc.). Individual names will be the final fields to undergo standardisation and will appear in the three major languages encountered in the sources (Romanian, Hungarian, and Latin).

The office table has been the first standardised, and exposes the main difficulty encountered in building the conceptual framework of the database, namely the differences in terminology between the official vocabularies of the two Romanian Churches. These differences mainly stemmed from the confessional poles towards which the ecclesiastical hierarchies gravitated: in the case of the Greek Catholic Church, Roman Catholic, Latin-inspired terminology was usually employed, while the Greek Orthodox Church maintained more of its Byzantine (Greek) lexicon. Given that the great majority of offices were structurally equivalent, we created a column of standard office titles in English, with columns listing the Latin and Romanian equivalents. Thus, the Orthodox "presbiter" and the Greek Catholic "protopop" designated the same official, namely the head of a deanery ("tract presbiterial", "protopresbiteriat", "protopopiat", "district protopopesc"): both versions were standardised with "dean/decanus/protopop", in order to avoid unnecessary proliferation of confession-specific variants. Similarly, we decided to standardize so-called office statuses: many of the priests or the teachers at confessional schools were listed "pensionat" (retired), "ambulant" (travelling, meaning teaching at several schools in neighbouring parishes), "interimar" (temporary or substitute). We dealt with offices that were singled out as being exerted in a certain ecclesiastical administrative unit, such as the deanery ("administrator protopopesc") or the parish ("administrator parohial") by linking a particular office to the precise administrative unit in which it was exerted: thus, a temporary or substitute parish administrator was standardized as an individual exerting the office of administrator, with the attribute "temporary" in a certain parish. Likewise, a deanery administrator was linked to the office of administrator (full) in a certain deanery. This eliminated the great majority of office descriptions listed in the schematisms, rising as high as 700 , to only some 40 standard offices, with other attributes. The standard office table also contains meta-variables created in order to help researchers who are perhaps not entirely familiar with both ecclesiastical hierarchies and to aid in the study of broader groups of clergymen: offices exerted at diocese level were coded as "upper level", those in the parish "low-level", and those in structures that bridged these units, such 
as defenders or prosecutors in ecclesiastical courts as "mid-level". ${ }^{22}$

\section{Conclusion}

Ecclesiastical history in Transylvania has a well-established tradition, and many works have been published on the Greek Catholic and Orthodox churches in modern times. Researchers have examined the Church-State relations, how the network of confessional schools supported by these two institutions contributed to cultural development of the Romanians in Hungary, the involvement of the clergy in the efforts of the First World War, and many other tangent topics. However, very rarely have these research endeavours resulted in structured datasets that could be integrated and harmonized in order to paint a broader picture. The reasons for this are manifold, but its outcome is relevant for the entire field: fragmented analyses still predominate, comparisons across broad time periods and geographical areas are not possible, and broader topics are difficult to tackle. We argued that the creation of the database is therefore direly necessary, if only in order to overcome these issues. As long as researchers continue to work on their own, with little aid from or contributions to digital infrastructures, it will be difficult to make broader arguments.

Our decision to start our data entry and database design endeavour with the most obvious choice of source material, namely the schematisms produced by the two Romanian Churches in Transylvania, will hopefully allow us to lay a strong and reliable foundation in digitally-focused ecclesiastical history in this part of Europe. Seeing as they cover all aspects of ecclesiastical structure, from the complex hierarchy of administrative and jurisdictional units, to the material underpinnings of parishes such as church and school buildings, and finally to the most often discussed individual staffing of positions, these sources can rightfully be said to constitute the central node in the network of records produced by ecclesiastical institutions. Any and all further sources that mention priests or parishes from the area under study, regardless of the institutional context in which they were produced or their structures, will be linkable at least to a certain degree to the data currently under definition, as long as they fulfil one major condition. The information they contain referring to either of the main entities in the database (in-

${ }^{22}$ A complete overview of the constructed variables and standardisation system implemented will be available on the website, with links to the relevant secondary literature that aided in identifying these structural equivalencies. 
dividuals or ecclesiastical units) must allow for the identification of correspondences with particular entities in the standard database: priests with very common names, for whom no other contextual information regarding education or parish location is known, will be difficult to link with a high degree of certainty. Likewise, the lack of a clear source timestamp will generally encumber if not wholly prevent linkage of such information to the data systematized in our infrastructure. Nevertheless, even more tenuous ties between database entities and various subjects identified in other researcher-produced datasets can in the future be verified and attributed a higher likelihood of identity, should this be the case.

To conclude, we hope that this will be a useful instrument for social historians not only in Transylvania, but also beyond. We think that the data entered will have immense linkage potential, for instance to the HPDT, but also to other datasets and contexts where priests make their appearance. After we will have included data from other sources, such as records pertaining to priests' income, to their families, and to their education, a lot more insight will be gained from this. What is more, due to the high level of standardization and the clear explanation of the database structure, we hope to make it useful and usable first of all for social historians and specialists in ecclesiastical history of Transylvania who are not experienced in using digital tools in their analysis.

\section{References}

Andrei, Mirela. (2006). La graniţa Imperiului: Vicariatul Greco-Catolic al Rodnei în a doua jumătate a secolului al XIX-lea. Cluj-Napoca: Argonaut.

Balog, Iosif Marin. (2014). "The Clergy's Involvement in the Romanian Credit System from Transylvania during the Late Nineteenth and the Early Twentieth Centuries. Case Study: the Greek-Catholic Clergy." In Recruitment and Promotion among the Romanian Greek-Catholic Ecclesiastical Elite of Transylvania (1853-1918): A Collection of Studies, edited by Mirela PopaAndrei et al., 163-180. Cluj-Napoca: Mega Publishing House.

Bökös, Borbala. (2017). „Representations of Hungary and Transylvania in John Paget's Travelogue." Acta Universitatis Sapientiae, Philologica 9, 1 (2017): 87-98.

Brusanowski, Paul. (2005). Învăţământul confesional ortodox român din Transilvania între anii 1848-1918. Intre exigenţele statului centralist şi principiile autonomiei bisericeşti. Cluj-Napoca: Presa Universitară Clujeană.

Brusanowski, Paul. (2007). Reforma constituţională în Biserica Ortodoxă a Transilvaniei între 1850-1925. Cluj-Napoca: Presa Universitară Clujeană. 
Brusanowski, Paul. (2017). „Katholiken und Orthodoxe in Siebenbürgen und im rumänischen Altreich. Verschiedene Modelle von religiöser Toleranz und des Lebens miteinander." In Dialog 2.0 - Braucht der orthodox-katholische Dialog neue Impulse?, edited by Dietmar Schon. Regensburg: Verlag Friedrich Pustet.

Burns, Arthur, Fincham, Kenneth, and Taylor, Stephen. (2004). "Reconstructing Clerical Careers: The Experience of the Clergy of the Church of England Database." The Journal of Ecclesiastical History 4 (October 2004): 726-737.

Câmpeanu, Remus. (2003). Biserica Română Unită între istorie și istoriografie. Cluj-Napoca: Presa Universitară Clujeană.

Cârja, Cecilia. (2007a). „Instituții ecleziastice la românii din Transilvania în a doua jumătate a sec. al XIX-lea și la începutul sec. XX. Perspectivă comparată." In Identitate și alteritate. Studii de istorie politică și culturală, edited by Constantin Bărbulescu, Luminița Dumănescu, Sorin Mitu, and Vlad Popovici, 53-78. Cluj-Napoca: Argonaut.

Cârja, Ion. (2007b). Biserică şi societate în Transilvania în perioada păstoririi mitropolitului Ioan Vancea (1862-1892). Cluj-Napoca: Presa Universitară Clujeană.

Covaci, Diana. (2007). „Modalități de instituire a preoților în protopopiatele greco-catolic și ortodox ale Reghinului în a doua jumătate a secolului al XIX-lea.” In Identitate și alteritate. Studii de istorie politică și culturală, edited by Constantin Bărbulescu, Luminița Dumănescu, Sorin Mitu, and Vlad Popovici, 79-90. Cluj-Napoca: Argonaut.

Covaci, Diana. (2012). „For the Rest of Their Life: The Retirement of the Romanian Greek-Catholic Clergy." Transylvanian Review, Vol. XXI (Supplement), No. 3: 359-369.

Dăncilă-Ineoan, Andreea-Oana, and Iudean, Ovidiu-Emil. (2018). "The Activism of the Middle Clergy in Support of the National Desideratum: Romanian Archpriests at the Great National Assembly in Alba Iulia." Transylvanian Review 27 (3): 34-49.

Drăgoi, Macarie. (2011). Ortodocși și Greco-catolici în Transilvania (18671918). Convergențe și divergențe. Cluj-Napoca: Presa Universitară Clujeană.

Dumitran, Daniel. (2007). Un timp al reformelor: Biserica Greco-Catolică din Transilvania sub conducerea episcopului Ioan Bob: (1782-1830). ClujNapoca: Argonaut.

Floca, Ioan N. (1990). Drept canonic orthodox, legislație şi administrație bisericească. Vol II. București: Editura Institutului Biblic și de Misiune Ortodoxă al Bisericii Ortodoxe Române.

Genț, Ioan. (1912). Administrația bisericească. Oradea: Tipografia "Nagyvárad". 
Gubler, Kaspar, and Schwinges, Rainer C. (2018). Gelehrte Lebenswelten im 15. und 16. Jahrhundert. Zürich: vdf Hochschulverlag AG an der ETH Zürich.

Hitchins, Keith. (1994). A Nation Affirmed: The Romanian National Movement in Transylvania 1860-1914. Bucharest: The Encyclopaedic Publishing House.

Holom, Crinela, Sorescu-Iudean, Oana, and Hărăguș, Mihaela. (2018). „Beyond the Visible Pattern: Historical Particularities, Development, and Age at First Marriage in Transylvania, 1850-1914." The History of the Family, 23(2): 329-358.

Kubiska-Scharl, Irene, and Pölzl, Michael. (2013). Die Karrieren des Wiener Hofpersonals 1711-1765. Eine Darstellung anhand der Hofkalender und Hofparteienprotokolle. Forschungen und Beiträge zur Wiener Stadtgeschichte, Band 58. Innsbruck - Wien - Bozen: Studien Verlag.

Mandemakers, Kees, and Dillon, Lisa. (2004). "Best Practices with Large Databases on Historical Populations." Historical Methods: A Journal of Quantitative and Interdisciplinary History, 37 (1): 34-38.

Nedici, Radu. (2013). Formarea identității confesionale greco-catolice în Transilvania veacului al XVIII-lea. Biserică și comunitate. Bucharest: Editura Universității din București.

Paget, John. (1839). Hungary and Transylvania: With Remarks on their Condition, Social, Political, and Economical, vol. II. London: John Murray, Albemarle Street.

Panțuru, Cosmin. (2013). Parohia ortodoxă română Timişoara - Fabric: studiu istoric, canonic şi administrativ-bisericesc. Sibiu, Timișoara: Astra Museum, Editura Partoş.

Păcurariu, Mircea. (2013). Istoria Bisericii Ortodoxe Române: compendiu. Bucureşti: Basilica.

Popa-Andrei, Mirela, and Covaci, Diana. (2013). "The Recruitment of an Ecclesiastical Elite: the Canons of the Cathedral Chapters in Oradea and Blaj." Anuarul Institutului de Istorie „George Barițiu” Cluj-Napoca al Academiei Române. LII, Supplement: 115-138.

Popa-Andrei, Mirela, Covaci, Diana Maria, and Sima, Ana Victoria. (2013). Canonici, profesori şi vicari foranei din Biserica Română Unită (1853-1918): dicţionar. Cluj-Napoca: Mega.

Popa-Andrei, Mirela, Covaci, Diana, Bedecean, Mihaela, Dan, Aurelia, Balog, Iosif Marin (eds.). (2014). Recruitment and Promotion among the Romanian Greek-Catholic Ecclesiastical Elite in Transylvania (1853-1918). A Collection of Studies. Cluj-Napoca: Mega Publishing House.

Popova-Nowak, Irina V. (2008). "The Odyssey of National Discovery: Hungarians in Hungary and Abroad, 1750-1850." In Under Eastern Eyes. A 
Comparative Introduction to East European Travel Writing on Europe, edited by Wendy Bracewell and Alex Drace-Francis, 195-222. Budapest: CEU University Press.

Popovici, Vlad. 2018. "ASTRA'S Membership in the early 1900s." Studia Universitatis Babeș-Bolyai. Historia 63 (2): 36-61.

Sima, Ana Victoria, and Covaci, Diana. (2015). „The propaganda messages disseminated through Transylvanian ecclesiastical channels during World War I.” In Nouvelles Études d'Histoire, XIII: 141-152. Cluj-Napoca: Editura Academiei Române.

Sima, Ana Victoria. (2013). Affirming Identity: the Romanian GreekCatholic Church at the Time of the First Vatican Council. Milano: Vita e pensiero.

Suciu, Dumitru, et. al. eds. (2011). Biserică, școală și comunitate ortodoxă în Transilvania în epoca modernă: documente: protopopiatul Cetatea de Piatră și eparhia Sibiului: Corespondență 1849-1874. Vol II/1. ClujNapoca: Argonaut. 